\title{
Linguistic Freedom and Hate Speech: A Critical Review of Nigerian Politicians' Speeches and Their Implications
}

\author{
Dare Williams Omotoyinbo Ph.D \\ Department of Arts Education, Faculty of Education \\ Adekunle Ajasin University, Akungba Akoko, Ondo State, Nigeria
}

\begin{abstract}
This paper deals with the linguistic freedom of the people of Nigeria as entrenched in the constitution of the Federal Republic of Nigeria and the misuse of that freedom through hate-speech by Nigerian politicians against their opponents in the public for and even in the National Dailies. This paper condemns such actions in its entirety exposing the dangers involved and the implications both at present and in future. The paper goes further to give a better alternative to hate-speech, which is persuasion; this is believed to be more convincing than the former. The theories of persuasion were explained and elaborated. These theories are social judgment theory and the Relationship based persuasion theory. It concludes by saying that whatever the situation, it is when Nigerians see themselves as one, respect one another and work together, that Nigeria can stand tall in the comity of nations of the world. Based on the havoc and the hatred that hate-speech causes, the paper recommends that government should do everything possible eradicating this societal cankerworm or reducing it to the barest minimum, by taking drastic actions against perpetrators, because, to build Nigeria and make it one continually, is a task that must be done by all.
\end{abstract}

Keywords: Linguistic freedom, hate-speech, politicians, persuasion, societal cankerworm.

DOI: $10.7176 / \mathrm{NMMC} / 80-01$

Publication date:May $31^{\text {st }} 2019$

\section{INTRODUCTION}

Language, no doubt, is the greatest gift bequeathed to mankind at creation (going by innateness theory). The ability to use language places man on higher rank than any other entities which were created by God. Aristotle, while explaining the importance of language to man and his society, he posits that "... what raises him (man) above the animals is that he has the ability to reason, and it is very clear that he cannot reason without language". He states further that "that meaning was no less an integral part of language than the sounds which bear the meaning and that language depends no less on the rational powers of man by which meanings are constructed than on the physiological organs by which sounds are formed". Language, therefore, makes man a rational animal.

Etymologically, the word "language" is derived from the Latin word "langua" which means tongue. The association of language to the "tongue" is a pointer to the fact that language is primarily oral. It is in this wise that Block and Trager $(1942$, p.5) avow that ... language is a system of arbitrary vocal symbols by means of which a social group co-operates. Hence, language is a social phenomenon because it finds its relevance only in speech communities. However, language does not only exist in oral form, it also has the written variance. Language, whether verbal or written is used to communicate among social-groups.

Nobody has a clear stance as how human language evolved. However, going by what is contained in Genesis 11:1-9, the evolution of language is shrouded in the myth of Babel of Tower where it was stated that" "... the whole earth had one language and one speech". In other words, according to Wood (1969), at the very beginning of the world, the human beings had only one and unique language. If we read further, we would discover that God later caused linguistic confusion amidst them. This, therefore, compounds the linguistic situation of the people. Apart from this biblical assertion, nothing is again said as how languages of the worlds evolved. This shows that language is divine.

Language is such a rich social phenomenon. It has all the elements to thrive anywhere, situation etc. Though, the linguistics elements that make up each of the languages differ. English language, for example, has forty-four (44) speech sounds, Hausa language also has forty-four speech sounds, where Igbo language and Yoruba language have thirty-two and twenty-five speech sounds respectively. In the same vein, syntactically, infinite number of sentences can be constructed from the finite set of rules that govern each of the languages of the world. In a communication process, a speaker has access to unlimited number of linguistic items to choose from. For instance, a typical speaker can decide to choose one from the under-listed words depending on what information $\mathrm{s} / \mathrm{he}$ has in mind:

He killed her

He murdered her

He lynched her

He poisoned her 
From the options above, what is of relative importance is the fact that someone is dead. It is now left for the speaker to choose the right word that will best convey his/her messages. From the foregoing, it is apposite to state that wrong selection of lexical items then will only convey wrong information. Wrong information, therefore, may incite violence or attacks.

In democratic societies, there are basic fundamental human rights that citizens enjoy. One of such rights is the freedom of expression. Fundamental human rights are based on the principle of equality in the freedoms and rights of all people around the world. This freedom, according to Beston and Cripps (2000) is vital to promote peaceful coexistence in multicultural societies. Every person has the right to express and disseminate his own opinions, and the right to access, receive and share information and ideas in any medium, whether it is audible or written, including modern means of communication. Accordingly, freedom of expression, as a profound concept, includes a set of rights, such as: the right to privacy, religion or belief, cultural or political affiliation, and freedom of the press. In a similar vein, International Covenant on Civil and Political Rights (ICCPR) (1976) states that:

1. Everyone shall have the right to hold opinions without interference.

2. Everyone shall have the right to freedom of expression; this right shall include freedom to seek, receive and impart information and ideas of all kinds, regardless of frontiers, either orally, in writing or in print, in the form of art or through any other media of his choice.

3. The exercise of the rights provided for in paragraph 2 of this article carries with it special duties and responsibilities. It may therefore be subject to certain restrictions, but these shall only be such as are provided by law and are necessary:

a) for the respect of the reputation or rights of others

b) for the protection of national security or of public order, or of public health or morals.

However, freedom of expression can be subjected to limitations and restrictions as is the situation with most human rights. This restriction is usually placed for the interests of other persons or to those of the community as a whole (High Commissioner of human right, 1983). In order to keep our society in unity, we should checkmate our language use..

\section{LINGUISTIC FREEDOM}

Linguistic freedom which may also mean "linguistic rights" are the human and civil rights concerning the individual including a collective right to choose the language or languages for communication either in the private or in the public. This may include the choice of words or diction one intends using to express his or her opinion, emotions, ideas etc. Linguistic freedom may not exclude the right to one's own language in legal, administrative and judicial acts, language education, and media. In international law, linguistic right usually deals with the wider framework of territorial and educational freedom.

According to Section 39 (1) of the 1999 Constitution every Nigerian has the freedom of speech and expression. It says ' $E v e r y$ person shall be entitled to freedom of expression including freedom to hold opinions and to receive and impart information without interference. Other human right charter to which Nigeria is a signatory, preach same freedom of expression. However, where a citizen's rights stop, there the rights of others commence. Nobody is saying those in power cannot be criticized but the criticism should embrace where those in power have not done well with evidence of proof and authenticity. Show where they need adjustments or totally deviate from programmes that have no direct benefit for the electorates. That is talking of constructive criticisms that will unite and benefit the people in various ways.

\section{AN OVERVIEW OF HATE SPEECH}

What is Hate Speech? Wikipedia the online encyclopedia says 'hate speech is speech that attacks a person or group on the basis of attributes such as race religion ethnic origin national sex or disability sexual orientation or gender identity Hate speech to this paper is more than the verbalization of venom directed at persons on the basis of the attributes above. It can be verbal or non verbal words or actions. Hate speech may mean utterances, handwritten, typed documents advertorials, musicals or any form of writing used to attack an individual, a group like religious, political, business ,social, gender or race.. According to Dictionary.com, 2011, Hate speech is any speech that attacks a person or group of on the basis of attributes like gender, ethnic origin, religion, race, disability or sexual orientation. Ezeibe (2015) says "'Hate speech is any speech, gesture, conduct writing or display which could incite people to violence or prejudicial action. Speeches based on false and bias ideas .It may include any none-verbal communication or body language and micro-expressions which may even incite the deaf and dumb to unwholesome actions. Essentially, such speeches or actions rob others of their dignity and honour.

Hate speech uses insulting, discriminatory, degrading and derogatory words to stigmatize and deride others based on their group or political membership, race, ethnicity, gender, sexual orientation. Segun (2015) says ' Hate speech is often the gateway to discrimination, harassment and violence as well as a precursor to serious 
harmful criminal acts". It may not be far from the truth to say that there is no hate motivated attacks on the opposition group without hate-speech from a clandestine angle.

Hate speech is not a recent phenomenon, but there are varying degrees to which they occur. Morphologically speaking, hate-speech is a compound word comprising of two words "hate" and "speech". The preceding word belongs to the grammatical class of adjective and it qualifies the noun speech. Hence, Okafor \& Alabi (2017) are of the view that hate speech are "words that wound" which can lead to harm and violence. Following the belief of Jane Austin's (1962) in "How to Do Things With Words" where he purposely states that when an utterance is made, an action is being performed. Relating that to hate speech, it implicates that when somebody makes a hate speech, s/he is inciting people to violence. In similar manner, Neisser (1994) refers to hate speech as all communications (whether verbal, written, symbolic) that insult a racial, ethnic and political group, whether by suggesting that they are inferior in some respect or by indicating that they are despised or not welcome for any other reasons. In other words, engaging in hate speech is inciting verbal war. Hate speech may take the form of defamation, calumny, vilification, or inducement which results to the communication of a false statement that harms the reputation of others depending on the law of such a country, an individual, business, product, group, government, religion or nation.

Today, unlike many years in the past, hate speech is deployed by the ego-massaging individuals to prepare the ground for acrimonious and hostile political disruption and controversy. They can cause religious, communal and ethnic chauvinism ending in violence and kidnapping in Nigeria. They sometimes use media to propagate hate-speech, taking cultural, political economic and social dimensions to cause crisis and cruelty among the innocent masses.

\section{ANTHOLOGIES OF HATE SPEECH}

A report from the Nigerian civil society in 2015 cited some hate speeches employed during the 2015 general elections campaign in its report titled "Hate speech Issue based campaigns and the 2015 General elections" : Katsina State Governor Shema reportedly urged his supporters to attack opponents; which he referred to as 'cockroaches' urging his supporters to kill them as one kills cockroaches.

One time Ekiti State Governor, Peter Ayodele Fayose in January repeatedly in the front pages of Newspaper advertorials (adverts widely known as "death wish advertorials") warning voters not to vote for the APC presidential candidate- Muhammadu Buhari. According to Fayose, Buhari was likely to die in office like the late President Yar' adua. Voting for him was like voting for a ghost. Fayose was making some Nigerians (his followers) nursed a belief that another National burial on mourning was impending.

Speaking during the PDP women presidential campaign rally in Kogi State, the then Nation's First lady in a documentary titled "Lion of Bourdillon' In the hour-long documentary First Lady reportedly described General Buhari (retired) as unfit to be the country's president calling him 'old and brain dead'.

One time Nigerian First lady, Patience Jonathan is also recorded as urging the members of the People's Democratic Party (PDP) to stone anyone that promised them 'Change' which was the slogan of the All Progressive Congress (APC)

In the same campaign speech given at a rally held on Monday, March 2, in Calabar, the capital of Cross River state, Mrs Jonathan is quoted as saying "Our people no dey born children wey dem no fit count". "Our men no dey born children thro-way for street". "We no dey like the people for that side" She was making derogatory remarks referring to the Northern parts of the country where people observe, as most prominent, the awful practice of child abandonment known as "Almajiri"

After the plethora of criticism that followed the documentary on General Muhammadu Buhari, Presidential candidate of the APC earlier in the year, a popular television Network, AIT, on March 1st aired a documentary titled Lion of Bourdillon", The hour-long documentary aired at 11p.m, showcased various property and companies across Lagos purportedly owned by Asiwaju Bola Ahmed Tinudu, a top leader of the APC describing him as "Nigeria's biggest landlord" It also alleged that the APCN chieftain was "charged for narcotics" in 1993.

Oba Akinolu of Lagos on April 3rd 2015 said " on Saturday if anyone of you, I swear in the name of God, goes against my wish that Ambode will be the next governor of Lagos state, the person is going to die inside this water... For the Igbos and others in Lagos, they should go where the Oba of Lagos heads to"

Alhaji Mujahid Dokubo-Asari said “.....2015 is more than do-or-die. You are a man and I am a man, we are going to meet at the battle-field" (News Express 3rd May, 2014) Mujahid Dokubo-Asari on Channels Television also said that General Muhammadu Buhari of the APC is "'a beast clothed in human skin and would ensure he does in his power, to make sure he does not become president of the Federal Republic of Nigeria." El Rufai was quoted by Sunday Vanguard (p 5) of 11 th November, 2018 as calling Peter Obi a 'Tribal Bigot'"

Many political watchers, local and international observers and of course the entire citizenry are concerned about the spate of hate speeches that characterized the political campaign messages and adverts of the two main political parties. Nigerians are tired of basket-mouth politicians who see nothing good in any other apart from 
himself. Where are the novelty in the performances of those causing breaks and brigandage in our politics? Are they and their opponents not the same? What makes the difference? Most of those hate speeches are tricks of calling the dog a bad name so as to hang it. Why should the kettle call the pot black? Just breaking the nation into fragments and making people ungovernable for the opposition party. What has that benefited our Nation? We should all know we cannot build the future of Nigeria with the bricks of division and hate, therefore our politicians and leaders should learn to bridle their tongues.

The Vice President of Nigeria, Professor Yemi Osinbajo, raised an issue that was then playing in the public space, about this hate speech. He warned that "hate speech precedes genocide, the greatest tragedy in human history". He said this while addressing the participants during the national seminar on unity in diversity at the Department of state Services hosted in Abuja. The Christian Association of Nigeria (CAN) equally urged government to sanction members allegedly fuelling insecurity in Nigeria. Kudos to those individuals and groups of people who fore-see the evil of hate speech. However, we should not only verbalize the hate for hate-speech, drastic actions should be taken without hesitation.

Nigeria could learn from the Chilean law against hate speech as found in Article 31, of the statue on press of their freedom saying "anyone, who, through any means of social communication makes publication or transmissions intended to promote hatred for a group of persons due to their race sex religion or nationality will face the full wrath of the law". The Maltese law on hate speech also stipulates that "whosoever uses any threatening, abusive or insulting words or behaviour or displays any written or printed material which is threatening, abusive or insulting or otherwise conducts himself in such a manner, with intent thereby to stir up violence or racial or religious hatred against another person or group on the grounds of gender identity, sexual orientation, race, colour, language, ethnic origin, religious belief or political or other opinion whereby such violence or racial or religious hatred is likely, having regard to all the circumstances, to be stirred up, shall on conviction, be liable to imprisonment for a term from six to eighteen months". Some other countries of the world have similar laws against hate speech. Why should Nigeria fold her arms? Stopping the spread of hate speech in Nigeria, this paper believes, will help to curb the inherent human tendency to profile those who are different from us politically and in other areas of life and exploit their powerlessness as minority or inferior. We should not allow views of division and discrimination to become endemic within our communities. Hate speech is a matter that should concern us like the public health. Hate-speech is like a social disease, which has the characteristics of a contagious disease like the HIV/AIDS, and such should not be allowed to spread.

\section{IMPLICATIONS OF HATE SPEECHES}

The 2015 General elections in Nigeria, witnessed series of hate speeches being used by politicians against their opponents and opposition parties. This statement was corroborated by the Chairman of the National Human Rights Commission (NHRC). Professor Chidi Odinkalu, confirming that the 2015 general election witnessed a rise in hate speeches during the campaign prior the election. Emanating from this, the election witnessed violence and killings in different parts of the country. In fact, there were fears on the minds of masses, and many people envisaged that the country was on the edge of precipice and total disintegration. Thank God for His prompt intervention.!

Ayo-Aderele (2015) in his paper published by Punch Newspaper on March 10, 2015 with the caption "When Hate Speeches Threaten Election"' There he decried the hate speeches that characterized political campaigns in Nigeria. He added that the hate speeches ranged from both uncouth, to the uncultured and absolutely damning statements emanating from both camps of the PDP and the APC. Nigerians could not have heard anything more surprising in recent times as far as political campaigns are concerned in the country. Hate speech affects and pollutes electoral processes, disrupts opposition, political, and civic norms. The attack and condemnation of the person of Asiwaju Bola Ahmed Tinubu and the APC presidential candidate, General Muhammadu Buhari (Now President) by politicians in a documentary aired on African Independent Television (AIT) warranted the Nigerian Broadcasting Commission to indict and sanction the two television stations alongside 21 others for violation of its code. (Nigerian-eye 28, 2016) This step, more or less, will affect the lives of some innocent citizens in the families of those concerned. For instance, if the salaries of the workers of such a Television station were not paid, it will be cumbersome for them to take care of their families. The feelings of children from such families at that critical and trying period may be incredibly unimaginable!

\section{PROHIBITION OF HATE SPEECHES}

In law, hate speeches include any speech, gesture, any body language, conduct, writing or display which is forbidden, because, it may incite violence or prejudicial action against or by a protected individual or group or because it disparages or intimidates a protected individual or group. In Nigeria today, we do not seem to have a law against hate speech. Many Television and radio stations not excluding Newspapers, fail to live up to their social responsibilities in Nigeria as many politicians use them as propaganda tools during campaigns, prior or even after elections. They are used after elections to water-down the good and laudable programmes of many 
seating governments. The media has since become a tool for negative mobilization and dissemination of hate speech, which appeals mostly to the irrational impulses of the unemployed hungry and angry youths. A concerted effort should be put in place regulating the use of hate speeches for political reasons. Let hate speeches be condemned in its entirety and such actions be termed defamation of character, which should be punishable by the law of the land The bidding of Lt General Abdulrahman Dambazzau that the office of the Attorney-General would soon submit a bill to the National Assembly that aimed to curtail hate-speech should be put in a fast-lane in the house.

\section{A BETTER OPTION FOR HATE-SPEECH}

Political posts could easily be won by an option segmented from hate-speech. To sell ones goods in the market, one does not need tarnishing the image of the other sellers, but employing business tactics that will compel customers patronize him/her. There is a business acumen that has never failed either in the urban or rural settings. This potent magical option is "Persuasion"

\section{PERSUASION:}

What is persuasion especially in public speaking in which most politicians are engaged? Persuasion is getting someone to do or believe, or accept something by means of the words you use. It involves reasoning with the listener(s) using sound arguments or a compelling entity to convince.

According to Perloff (2003) persuasion can be defined as.... a symbol process in which communicators try to convince other people to change their attitude or behaviour regarding an issue through the transmission of a message in an atmosphere of free choice.. Is that not the freedom of association entrenched in our constitution? Persuasion is to get the support of people through the use of words, action or any other means of entreaty. True persuasion is ethical, honest, truth and elicits the persuasion criteria that is hard wired into our brains. Persuasion is not the negative kind of manipulation that goes on around us especially in our politicking and political processes in Nigeria. Persuasion, unlike manipulation, is not selfishness. Persuasion benefits both the persuader and the persuaded. Persuasion follows a specific pattern of processes, methods and tactics that motivate one to help others. Most public campaigns are not persuasive but manipulative. That may be one of the reasons why politicians forget or discard their so-called manifestoes to the dismay of the electorates after winning elections. They see these electorates as mere tools used to gain their selfish interests and later dump them. They (politicians) appeal to be sent, promising to represent the people, but fail to report to them (masses) not until they need their votes again, pretending to be humble and using some ridiculous amounts or insulting rice-contents to manipulate the hungry citizens. However, as persuasion results in a long-lasting relationship, and could be used to sustain or strengthen existing attitudes or behaviour, manipulation will collapse in no longer period of time, it does not create lasting relationship, and will always eventually fail- Oppression does not last forever.

\section{THEORIES OF PERSUASION}

There are Theories which Politicians may be advised to consider when making public speeches in order to win the hearts of men of integrity to their sides during elections. The theories are; Social Judgment theory and Relationship Based Persuasion Theory. The first theory hinges on two key concepts: anchor and ego involvement. However, this paper will delve on the anchor concept only because of space. Both concepts represent internal points of reference that we all have. When we assess people, issues, opportunities, ideas, products and the like, we compare them with these internal points of reference in order to make a decision. Anchor points refer to information on a specific issue which thus forms part of frame of reference. We compare the situation we are facing with our existing knowledge about it in order to arrive at a decision. For example, suppose a would be politician has been good to the people in his environment and they have been observing his patriotic activities in the community, such a person may not need to talk his bowels out before he wins the hearts (support) of the majority of those surrounding him as they are bound to make reference to his achievements in the past, and those who know him will propagate his ideals to others who will embrace him with equal magnanimity. In deciding whether to vote for him or not, people would consider several internal points of reference (anchor points) and decide to compensate his anaphoric endeavours. Social judgment and involvement theory predict that one will compare the proposal about voting for the candidate in question; with these anchor points before them, the electorates will take a decision to vote for the right candidate. Their decision naturally, is made purely on their anchor points (existing knowledge) of the candidate. These anchor points function on a continuum ranging from full acceptance because of the agreement of the people about the candidate through neutrality to rejection (because of conflict with the anchor points) To vote for any candidate during election, many electorates would support, oppose or be persuaded either way, depending on the extent to which the facts of the matter agree or conflict with the existing anchor points.

The second theory is the "Relationship-Based Persuasion" Theory

Richard Shell and Mario Moussa (2007), present a four-step approach to strategy persuasion which they 
described as "Relationship Based Persuasion Theory" They explained that persuasion means to win others, not to defeat them. Thus, it is important to be able to see the topic from different angles in order to anticipate the reaction others have to a political or business proposal.

Step 1: Survey your situation: This step includes an analysis of the persuader's situation, goals and challenges that he or she faces

Step 2: Confront the five barriers: Five obstacles pose the greatest risks to a successful influence-encounter: relationships, credibility, communication mismatches, belief systems, interest and needs.

Step 3: Make your pitch: It is indisputable that people need a solid reason to justify a decision, at the same time, many decisions are made on the basis of intuition. This step, the authors admit, deals with presentation skills. How do you present your points? How do you sell your manifestoes to the people? Caution needs be taken by every person making an election campaign. For instance, s/he must realize that he/she is addressing a homogenous and heterogeneous audience. (the supporters, those on the opposition party and the neutral people that you need to persuade to join you.), Both homogenous and heterogeneous audience might not listen to campaigners the same way. Their interpretation of what is said may mean different things to them. Things may go smoothly in one direction, but, they would start running into problems in the other. Such a campaign may hit a rough patch eventually if care is not taken.

Step 4: Secure your Commitments: In order to safeguard the longtime success of a persuasion decision \{to forestall political cross- carpeting\}, it is vital to deal with politics at both the individual and organizational level. Most of our politicians are losing credible members because they (politicians) believe the insulting quantity of rice and ridiculous amount of money given to them before elections will sustain their membership, forgetting that people are naturally flexible and make decisions based on intuition and not on reasons alone. Many campaigns that are done, instead of applying these principles and theories, engage in "Hate Speech" which in most cases do not stand the test of time. After spending valuable money and time speaking to the people, they in most cases have discussed nothing in particular, certainly, not anything important. Instead, these politicians must have successfully created eternal enemies for themselves, emanating from such careless utterances. Incredibly as it may sound, such avoidable enmity is usually prolonged beyond office tenure. To protect our posterity, fanning the embers of discord and disintegration should be stopped without further delay.

\section{CONCLUSION}

This paper concludes by saying, Politics of bitterness and hostility engineered by hate speeches made by politicians should not be allowed in Nigerian political system. Whatever the party of affiliation, ethnic group, religion or social class, we are Nigerians. All the ethnic groups were involved when fighting for independence from our colonial masters, and the rights of individuals, no matter which side of the country such an individual hails from, should be guaranteed. Every citizen's security should be ascertained without any fear of intimidation or molestation (the embers fanned by hate speech). We should see ourselves as brothers and sisters, respect ourselves; though tribes and tongues may differ, we should jettison our differences, come together to build a nation where peace, equity and justice prevail. Since we cannot build the Nigeria of our dream with the bricks of hatred and chauvinism, we should learn how to edit our speeches, encouraging unity, which is an inevitable tool for progress and power, in order to make our country raise her voice in the comity of great countries of the world.

\section{RECOMMENDATIONS}

*Those politicians who have stepped on toes through hate speech should tender an unreserved and public apology and those offended should embrace forgiveness with the understanding that two wrongs cannot make a right.

*We should note that politics is a game where one team is bound to win and the other to lose. Those who win should be humble in victory and the losers show magnanimity congratulating the winners. If you lose today you may win tomorrow.

*Such speeches to be made public should be edited by leaders of political parties, who should equally warn their supporters and be sure their speeches are devoid of hate, division and insult. Many potential office holders have lost their political career and opportunities through unscrupulous and careless talks in the name of political campaigns. Caution should be taken in the preparation and delivery of political speeches..

*Would be political office holders should be careful not to jeopardize the future of their children through creation of unnecessary enemies for their families and posterity. Nobody knows those one will offend and will never forgive and may decide to retaliate by all means even to generations yet unborn. We should try to avoid speeches that will create uncertainty for innocent children

*Government should not only make laws banning hate speech but should ensure such speech makers are prosecuted either by serving a jail term or paying a huge sum of money or both and restraining such personality from participating in partisan politics for a number of years to serve as deterrent to others. 


\section{REFERENCES:}

https://www.courses.psu.edu/spcom/spcom210 nxj6/language.html

https:// wwwVanguard ngr.com Dec 26, 2018

https:// enn,Wikipedia. org

Mc Keon, Richard (1946). Aristotle's Conception of Language and the Arts of Language in Classical Philology. Volume XLI, No.4. University of Chicago Press, Chicago, October 1946, p. 194.

Wood, F.T.: An Outline History of the English Language. Macmillan India Ltd, Chennai, 1969, p. 9-10.

The International Covenant on Civil and Political Rights, Adopted and opened for signature, ratification and accession by General Assembly resolution 2200A (XXI) of 16 December 1966, entry into force 23 March 1976, Article 19.

Beston and Cripps, Freedom of expression and freedom of information: essays in honour of Sir A. Mason, p. 17 (Oxford University Press, Oxford 2000)

Office of the High Commissioner for Human Rights, General Comment No. 10: Freedom of expression (Art. 19), paragraph 4, 19th session on 29/06/1983.

Perloff, R. M.(2003) The Dynamics of Persuasion :Communication and Attitudes in the 21st Century. New Jersy: Lawrence Erlbaum Associates, Inc.

Richard Shell \& Mario Moussa (2007), The Art of Woo, Barley, New York: Kegan Paul. 